\title{
Effect of mutagenic agents on seed germination and vegetative growth of mustard (Brassica rapa)
}

\author{
N. F. Khan*, N. Hassan, M. R. Islam and S. K. Biswas \\ Department of Biotechnology and Genetic Engineering, Islamic University, Kushtia.
}

\begin{abstract}
The experiment was conducted to study the effect of mutagens (physical and chemical) on seed germination along with root and shoot lengths of two locally collected varieties of Brassica rapa denoted as variety-1 and variety-2 in in vitro condition. Seeds were treated with various concentrations of mutagenic agents; physical (gamma radiation), chemical (sodium azide) and combined (gamma radiation + sodium azide). The doses of gamma radiation were $100 \mathrm{~Gy}$ and $200 \mathrm{~Gy}$, sodium azide concentrations were 100,300 and $500 \mathrm{ppm}$ and for combination, 100Gy and 200Gy gamma irradiated seeds were further treated with 100, 300 and 500ppm sodium azide solution. After 7 days observation, $100 \%$ seed germination obtained from 100Gy gamma irradiated seeds of variety-1 and 500ppm sodium azide treated seeds of variety-2. 100\% seed germination was also found in 7 days in physical and chemical mutagen combinedly treated seeds of variety-1 from $100 \mathrm{~Gy}$ gamma radiation $+100 \mathrm{ppm}$ sodium azide, $100 \mathrm{~Gy}$ gamma radiation $+300 \mathrm{ppm}$ sodium azide and 200Gy gamma radiation $+100 \mathrm{ppm}$ sodium azide and in variety-2, from $100 \mathrm{~Gy}$ gamma radiation $+500 \mathrm{ppm}$ sodium azide and $200 \mathrm{~Gy}$ gamma radiation $+500 \mathrm{ppm}$ sodium azide. Maximum increased root length (avg. $3.8 \mathrm{~cm}$ ) was obtained from variety-1 combined treated (200Gy gamma radiation $+300 \mathrm{ppm}$ sodium azide) seeds and minimum decreased root length (avg. $1.0 \mathrm{~cm})$ was from variety-2 combined treated (100Gy gamma radiation $+100 \mathrm{ppm}$ sodium azide) seeds. Maximum increased shoot length (avg. $4.7 \mathrm{~cm}$ ) was obtained from variety-1 combined treated (200Gy gamma radiation $+100 \mathrm{ppm}$ sodium azide) seeds and minimum decreased shoot length (avg. $1.4 \mathrm{~cm}$ ) was obtained from variety-2 combined treated (100Gy gamma radiation $+100 \mathrm{ppm}$ sodium azide) seeds.
\end{abstract}

Keywords: Mutagenic agents; Gamma radiation; Sodium azide; Combined treatment; Germination rate; Root length; Shoot length; Brassica rapa riety-1 and 2.

\section{Introduction}

Mustard (Brassica rapa) belongs to the family Brassicaceae is a biennial, economically important, oil producing herb, normally 1 to 1.5 feet in height with swollen tuberous whitefleshed taproot, leaves light to medium green, hairy or bristly, stalked, lyrate-pinnatifid, $30-50 \mathrm{~cm}$ long, flowers bright yellow, seeds blackish or reddish-brown, 1.5-2 $\mathrm{mm}$ in diameter, the root and leaf are reported to contain calories, water, protein, fat, carbohydrate, fiber, ash, $\mathrm{Ca}, \mathrm{P}, \mathrm{Fe}, \mathrm{Na}, \mathrm{K}$, a trace of beta-carotene equivalent, thiamine, riboflavin, niacin and ascorbic acid (Watt and Merrill, 1963; Wu Leung et al., 1972). Seed oil contains large amount of erucic, linoleic, and linolenic acids. Mustard has got strong medicinal properties; seeds are powerful anti-microbial agents and circulatory stimulant containing chemical components like isothiocyanates, omega-3 fatty acids, selenium, magnesium etc. (www.natradersonline.com). Mustard is a good antispasmodic herb and a diuretic, believed to have antiseptic properties, can destroy all the food borne pathogens quite effectively, stop the growth of cancer cells, helps in asthma,migraine and heart attacks, curative for the common cold, lowering blood pressure, used to treat bronchitis and pleurisy as well as helping arthritis and rheumatism and urinary ailments (Antol, 1999; Herbst 2001; Downey 2003). Induced mutation using physical and chemical mutagen is a method to create genetic variation resulting in new varieties with better characteristics (Wongpiyasatid et al., 2000; Arulbalachandran et al., 2009). Gamma ray and sodium azide used as physical and chemical mutagenic agent respectively; the genetic effects of ionizing radiation of gamma ray on DNA include rearrangements and deletions (Sax, 1963) and sodium azide cause alteration of the structure of the DNA (point mutation in the DNA, A.T-->G.C base pair transition and transversion) (Fahad and Salim, 2009). In this study, the effect of mutagenic agents on Brassica rapa seed germination and root and shoot development due to alteration in genetic material is analyzed.

\section{Materials and methods}

Two varieties of Brassica rapa seeds were collected from the locally cultivated plants. A portion of these seeds were used

\footnotetext{
*Corresponding author. e-mail: nowshin_btge@yahoo.com
} 
to treat by $\mathrm{Co}^{60}$ gamma irradiator from Atomic Energy Research Establishment (AERE), which is a source of gamma radiation. Two different doses 100Gy and 200Gy of gamma radiation were given (Akgun and Tosum, 2004). These seeds were pre-soaked with distilled water and plated on petridish. Another portion of locally collected seeds were treated with sodium azide solution prepared in different concentrations of 100ppm, 300ppm and 500ppm. These seeds were first presoaked in distilled water then immersed into sodium azide solution for three hours. These seeds were washed thoroughly under running tap water (Larik A, 1987). After washing, the seeds were dried in between filter paper folds. These seeds were then ready for plating on germination petridish. To create a modification some portions of locally collected seeds were combined treated. The combined treatment was, gamma radiated seeds of each dose were immersed into sodium azide solution of three different concentrations, after washing seeds were prepared for plating. Petridishes were prepared with sterile blotting papers and distilled water was poured on it to make the blotting paper wet enough for germination. Then seeds of different treatment category (physical, chemical and combined treated) with control group were plated on different petridishes and kept at normal environmental conditions age value of root and shoot length statistical analysis was performed by SPSS software (ver.15.0.1).

\section{Results and discussion}

For germination of seeds, after 7 days, the germination rate of control group in variety- 1 and variety- 2 were respectively $100 \%$ and $80 \%$. For physical treatment, in variety-1, 100Gy treated seeds gave maximum $100 \%$ germination \& 200Gy treated seeds gave $90 \%$ germination. In variety-2, both 100 Gy and 200Gy treated seeds gave the maximum 100\% germination. For chemical treatment, in variety-1, 100ppm and 300ppm sodium azide treated seed showed $90 \%$ germination and 500ppm showed $80 \%$ germination. In variety- 2 , $500 \mathrm{ppm}$ showed the maximum $100 \%, 300 \mathrm{ppm}$ gave $80 \%$ and $100 \mathrm{ppm}$ gave $70 \%$ germination. For variety- 1 combined treatment in combination with $100 \mathrm{~Gy}, 100 \mathrm{ppm} 300 \mathrm{ppm}$ gave maximum $100 \%, 500 \mathrm{ppm} 90 \%$ germination and in combination with $200 \mathrm{~Gy}, 100 \mathrm{ppm}$ gave $100 \%$, both the $300 \mathrm{ppm}$ and $500 \mathrm{ppm}$ gave $90 \%$ germination. For variety-2 combined treatment in combination with $100 \mathrm{~Gy}, 100 \mathrm{ppm}$ and $300 \mathrm{ppm}$ gave $90 \%$, 500ppm gave $100 \%$ germination and in combination with $200 \mathrm{~Gy}, 100 \mathrm{ppm}$ gave $70 \%$, 300ppm gave $90 \%$, $500 \mathrm{ppm}$ gave $100 \%$ germination. Variety-1 seeds and $100 \mathrm{~Gy}$ gamma ray gave better germination.

In the case of length of root \& shoot, for simplification, the results and discussion of root and shoot length are made up with the average value of five (5) germinated seeds after 7 days observations. Maximum increased root length $(3.8 \mathrm{~cm})$ was obtained from variety-1 combined treated $(200 \mathrm{~Gy}+$ $300 \mathrm{ppm})$ seeds, moderate results $(3.7 \mathrm{~cm}),(3.6 \mathrm{~cm}),(3.3 \mathrm{~cm})$ were also recorded from different mutagenic treatment in variety-1, and minimum decreased root length $(1.0 \mathrm{~cm})$ was from variety-2 combined treated $(100 \mathrm{~Gy}+100 \mathrm{ppm})$ seeds. Maximum increased shoot length $(4.7 \mathrm{~cm})$ was obtained from variety-1 combined treated $(200 \mathrm{~Gy}+100 \mathrm{ppm})$ seeds, moderate results $(4.2 \mathrm{~cm}),(4.1 \mathrm{~cm}),(3.6 \mathrm{~cm}),(3.5 \mathrm{~cm}),(3.0 \mathrm{~cm})$ were also got from different mutagenic treatment in variety1 , and minimum decreased shoot length $(1.4 \mathrm{~cm})$ was

Table I. Screening the effect of gamma radiation, sodium azide $\left(\mathrm{N}_{\mathrm{a}} \mathrm{N}_{3}\right)$ and combined treatment on seed germination and average root and shoot length of Brassica rapa varieties with control

\begin{tabular}{|c|c|c|c|c|c|c|c|c|c|c|c|c|}
\hline \multirow{3}{*}{ Variety-1 } & \multirow{3}{*}{$\begin{array}{l}\text { Control } \\
\text { group }\end{array}$} & \multirow{2}{*}{\multicolumn{2}{|c|}{ Gamma radiated }} & \multirow{2}{*}{\multicolumn{3}{|c|}{ Sodi }} & \multicolumn{6}{|c|}{ Combined treated } \\
\hline & & & & & & & \multicolumn{3}{|c|}{ 100Gy } & \multicolumn{3}{|c|}{ 200Gy } \\
\hline & & 100Gy & 200Gy & $100 \mathrm{p}$ & 300 & $500 \mathrm{ppm}$ & $100 \mathrm{p}$ & $300 \mathrm{ppm}$ & $80 \mathrm{P}$ & $100 \mathrm{P}$ & $300 \mathrm{ppn}$ & 500 \\
\hline \multirow{5}{*}{$\begin{array}{c}\text { Germination rate } \\
(\%) \text { Root } \\
\text { Length }(\mathrm{cm}) \\
\pm \text { STDEV Shoot } \\
\text { Length }(\mathrm{cm}) \\
\pm \text { STDEV } \\
\text { Variety-2 }\end{array}$} & $100 \%$ & $100^{\circ}$ & $Z^{0}$ & $90 \%$ & $90^{\circ}$ & $80 \%$ & $100 \%$ & $100 \%$ & $90 \%$ & $100 \%$ & $90 \%$ & $90 \%$ \\
\hline & & & & & & & & $3.7 \pm$ & $2.4 \pm$ & $3.6 \pm$ & $3.8 \pm$ & $3.3 \pm$ \\
\hline & 0 & 0 & 0 . & 0. & 0 . & & 0. & 0.44 & 0.21 & 0.26 & 0.22 & 0.22 \\
\hline & $\begin{array}{c}2.1 \pm \\
0.24\end{array}$ & $\begin{array}{c}3.0 \pm \\
0.26\end{array}$ & $\begin{array}{c}2.8 \pm \\
0.21\end{array}$ & $\begin{array}{c}2.2 \pm \\
0.13\end{array}$ & $\begin{array}{c}2.4 \pm \\
0.18\end{array}$ & $\begin{array}{c}3.0 \pm \\
0.21\end{array}$ & $\begin{array}{c}4.0 \pm \\
0.23\end{array}$ & $\begin{array}{c}3.6 \pm \\
0.15\end{array}$ & $\begin{array}{l}4.2 \pm \\
0.32\end{array}$ & $\begin{array}{c}4.7 \pm \\
0.19\end{array}$ & $\begin{array}{c}4.1 \pm \\
0.19\end{array}$ & $\begin{array}{c}3.5 \pm \\
0.19\end{array}$ \\
\hline & & & & & & & & & & & & \\
\hline \multirow{4}{*}{$\begin{array}{l}\text { Germination rate } \\
(\%) \text { Root } \\
\text { Length }(\mathrm{cm}) \\
\pm \text { STDEV Shoot } \\
\text { Length }(\mathrm{cm}) \\
\pm \text { STDEV }\end{array}$} & & & & & & & & $90 \%$ & $100 \%$ & 7( & $90 \%$ & $100 \%$ \\
\hline & $1.9 \pm$ & $1.6 \pm$ & $1.6 \pm$ & 1.7 & 1.5 & 1. & $1.0 \pm$ & $2.3 \pm$ & $1.9 \pm$ & $2.1 \pm$ & $2.5 \pm$ & $1.6 \pm$ \\
\hline & & & & & & & 0. & 0.18 & 0.24 & 0.40 & 0.19 & \\
\hline & $\begin{array}{l}1.8 \pm \\
0.20\end{array}$ & $\begin{array}{c}1.7 \pm \\
0.19\end{array}$ & $\begin{array}{c}1.8 \pm \\
0.17\end{array}$ & $\begin{array}{c}2.0 \pm \\
0.15\end{array}$ & $\begin{array}{c}1.8 \pm \\
0.19\end{array}$ & $\begin{array}{c}1.9 \pm \\
0.25\end{array}$ & $\begin{array}{c}1.4 \pm \\
0.16\end{array}$ & $\begin{array}{c}1.9 \pm \\
0.11\end{array}$ & $\begin{array}{c}1.8 \pm \\
0.24\end{array}$ & $\begin{array}{c}2.3 \pm \\
0.17\end{array}$ & $\begin{array}{c}2.5 \pm \\
0.31\end{array}$ & $\begin{array}{c}1.6 \pm \\
0.16\end{array}$ \\
\hline
\end{tabular}




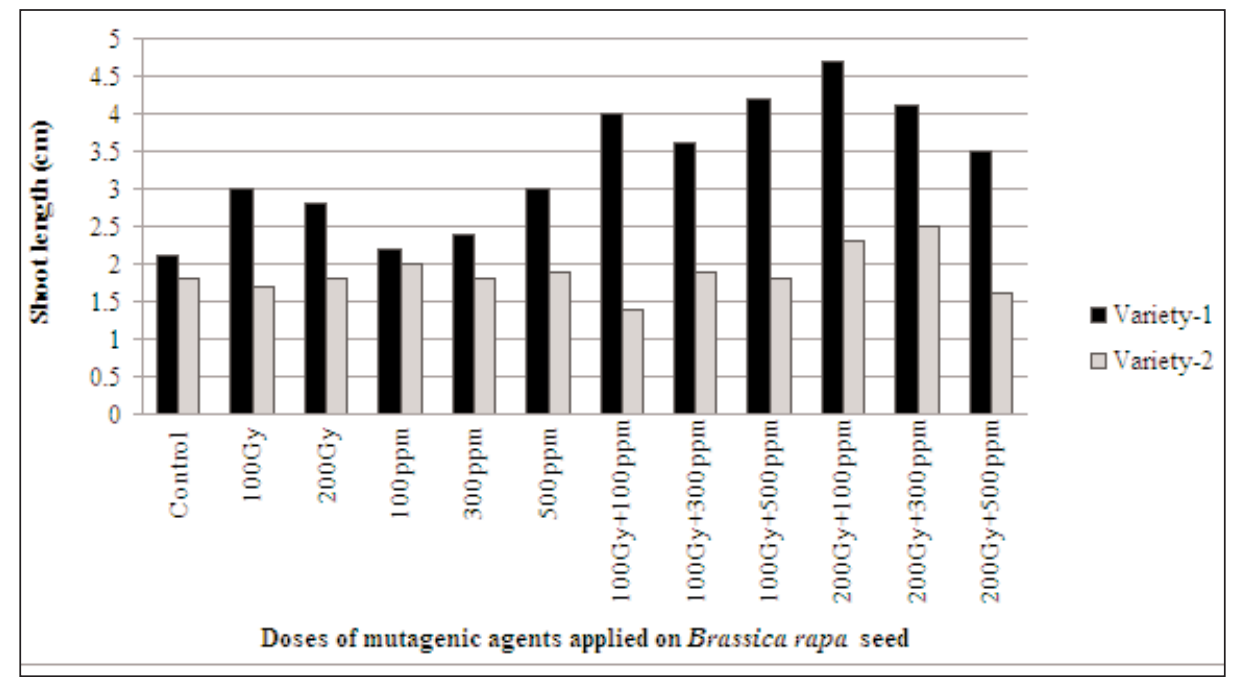

Graph-1: Inter-varietal comparison for root length development of Mustard (Brassica rapa) after applying different doses of mutagenic agent.

Table II. Significance determination by Statistical analysis (ANOVA) of the length of root and shoot of Brassica rapa seeds treated with different combination of mutagens

\begin{tabular}{|c|c|c|c|c|c|c|c|c|c|c|c|}
\hline \multirow[b]{4}{*}{ Variety-1 } & \multicolumn{11}{|c|}{ Level of significance (compared with control) } \\
\hline & \multirow{2}{*}{\multicolumn{2}{|c|}{$\begin{array}{c}\text { Gamma } \\
\text { irradiated }\end{array}$}} & \multirow{2}{*}{\multicolumn{3}{|c|}{$\begin{array}{c}\text { Chemical mutagen } \\
\text { treated }\end{array}$}} & \multicolumn{6}{|c|}{ Combined effect treated } \\
\hline & & & & & & \multicolumn{3}{|c|}{ 100Gy } & \multicolumn{3}{|c|}{ 200Gy } \\
\hline & 100Gy & 200Gy & $100 \mathrm{ppm}$ & $300 \mathrm{ppm}$ & $500 \mathrm{ppm}$ & $100 \mathrm{ppn}$ & $300 \mathrm{ppn}$ & $500 \mathrm{ppn}$ & $100 \mathrm{ppn}$ & $300 \mathrm{ppn}$ & $500 \mathrm{ppm}$ \\
\hline Root & 0.020 & 0.000 & 0.018 & 0.060 & 0.060 & 0.000 & 0.000 & 0.005 & 0.000 & 0.000 & 0.000 \\
\hline Shoot & 0.000 & 0.002 & 0.149 & 0.015 & 0.000 & 0.000 & 0.000 & 0.000 & 0.000 & 0.000 & 0.000 \\
\hline Variety-2 & 0.066 & 0.082 & 0.297 & 0.016 & 0.002 & 0.000 & 0.006 & 0.892 & 0.352 & 0.002 & 0.058 \\
\hline $\begin{array}{l}\text { Root } \\
\text { Shoot }\end{array}$ & 0.331 & 0.741 & 0.050 & 0.523 & 0.122 & 0.003 & 0.481 & 0.596 & 0.001 & 0.000 & 0.208 \\
\hline
\end{tabular}

Underlined values show significance at 0.05 level (Table II)

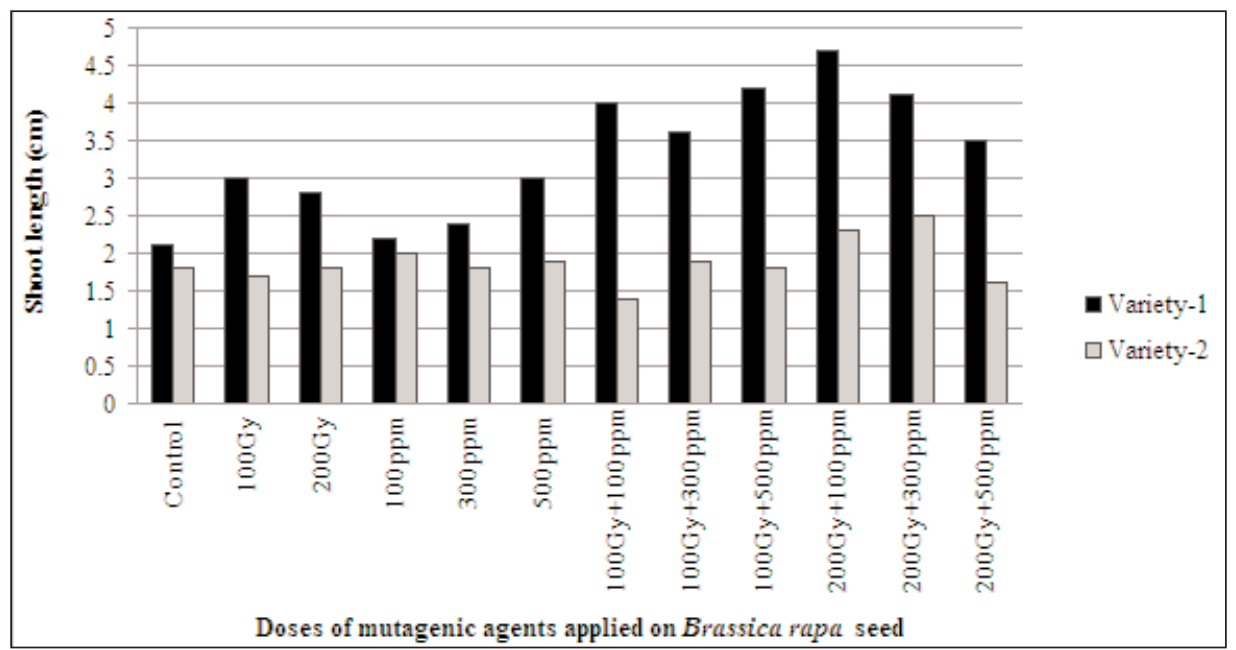

Graph-2: Inter-varietal comparison for shoot length development of Mustard (Brassica rapa) after applying different doses of mutagenic agent. 


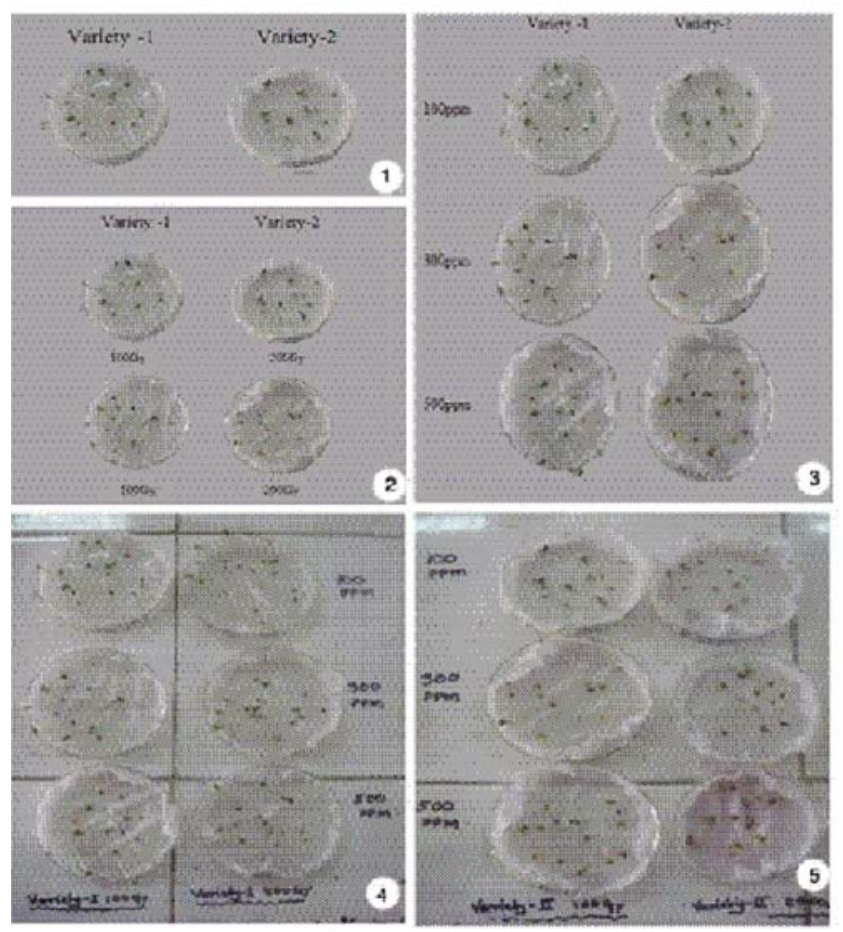

Fig. Effect of mutagenic agents on seed germination and vegetative growth of Mustard 1) Control seeds plated on petridish. 2) Physically treated seeds. 3) Chemically treated seeds 4) Combinedtreated seeds of varity-1. 5) Combined treated seeds of variety-2.

obtained from variety-2 combined treated (100Gy + 100ppm) seeds (Table I). Variety-1 and combined treated seeds gave better increased root and shoot length. Statistical analysis (ANOVA) (Lewontin and Hum, 1974) was performed with SPSS ver 15.0.1 (Mauric et al., 2010) to evaluate the significance at 0.05 level.

\section{References}

Akgun I and Tosum M (2004), Agricultural and cytological characteristics of M1 perennial rye (Secale montanum Guss.) as effected by the application of different doses of gamma rays, Pakistan J. Bio. Sci., 7(5): 827-833.

Antol MN (1999), The incredible secrets of mustard: The quintessential guide to the history, lore, varieties, and healthful benefits of mustard. Avery Publishing Group, p. 21 Making the most of... Mustard, BBC, retrieved 2008-02-06.

Arulbalachandran D, Mullainathan L, and Velu S (2009), Sreening of mutants in black gram (Vigna mungo L. Hepper) with effect of DES and $\mathrm{COH}$ in $\mathrm{M}_{2}$ genera- tion, J. Phytol., 1: 213-218.

Downey RK, Katz SH and Weaver WW (2003), Encyclopedia of food and culture, Gale virtual reference library, New York: Scribner. ISBN 0684314169.

Fahad AQ and Salim K (2009), Mutagenic effects of sodium azide and its application in crop improvement. World App. Sci. J., 6(12): 1589-1601.

Herbst ST (2001), The new food lover's companion: Comprehensive definitions of nearly 6,000 food, drink and culinary terms, Barron's Cooking Guide, Hauppauge, NewYork: Barron's Educational Series. ISBN 0764112589.

http://www.natradersonline.com.

Larik AS (1987), Mutagenic efficiency of individual and combined treatments of sodium azide and hydrazine hydrate in bread wheat, Wheat Information Service No. 64:6:1.

Lewontin R and Hum G (1974), The analysis of variance and the analysis of causes, 26: 400-11. Reprinted Int. J. Epidemiol 2006; 35: 520-25.

Mauric R, Ronak D and Yie Y (2010), Most pronounced diastolic left ventricular dysfunction in patients with accelerated idioventricular rhythm after reperfusion by primary percutaneous intervention, 574-578.

Sax K (1963), The stimulation of plant growths by ionizing radiation, Rad. Bot., 3: 179-186.

Watt BK and Merrill AL (1963), Composition of foods. USDA, ARS, Washington, DC. Agr. Handb. 8.

Wongpiyasatid A, Chotechuen S, Hormchan P, Ngampongsai S and Promcham W (2000), Induced mutations in mungbean breeding: Regional yield trial of mungbean mutant lines. Kasetsart J. Nat. Sci., 34: 443-449.

Wu L, Woot-Tsuen, Butrum RR, Chang FH (1972), Part I. Proximate composition mineral and vitamin contents of East Asian foods. In: Food composition table for use in East Asia. FAO \& U.S. Dept. HEW.

Received: 20 January 2013; Revised: 26 September 2013; Accepted: 17 December 2013. 